\title{
Human Capital and Social Capital: The Rise of Secondary Schooling in America, 1910-1940
}

\section{Citation}

Goldin, Claudia, and Lawrence F. Katz. 1999. "Human Capital and Social Capital: The Rise of Secondary Schooling in America, 1910-1940." Journal of Interdisciplinary History 29 (4) (April): 683-723. doi:10.1162/002219599551868.

\section{Published Version}

doi:10.1162/002219599551868

\section{Permanent link}

http://nrs.harvard.edu/urn-3:HUL.InstRepos:29429088

\section{Terms of Use}

This article was downloaded from Harvard University's DASH repository, and is made available under the terms and conditions applicable to Other Posted Material, as set forth at http:// nrs.harvard.edu/urn-3:HUL.InstRepos:dash.current.terms-of-use\#LAA

\section{Share Your Story}

The Harvard community has made this article openly available.

Please share how this access benefits you. Submit a story.

\section{Accessibility}


Journal of Interdisciplinary History, xxIx:4 (Spring, 1999), 683-723.

Claudia Goldin and Lawrence F. Katz

\section{Human Capital and Social Capital: The Rise of Secondary Schooling in America, I910-I940}

The landlord who lives in town has only a financial interest and must be reached from the financial side. He may well be reminded that when he offers his farm for sale it will be to his advantage to advertise, "free transportation to a good graded school."

Those who have no children to attend school are often indifferent as to school privileges, but they more than others should be interested in securing to the children of the whole community the best educational advantages possible. They may be secure and independent at present, but if they live out their years with no children to depend upon in old age, they must of necessity rely upon someone, they know not whom, who is today in the public schools. Their only safeguard lies in giving the best advantages possible to all.

Iowa Biennial Report, 1912/13, on the campaign for consolidated school districts

The United States led all other nations in the development of universal and publicly funded secondary school education, and much of the growth occurred from I9IO to I940. The focus of this article is on why the "high school movement" occurred in America generally and why it occurred so early and swiftly in America's heartland — a region we dub the "education belt." Since

Claudia Goldin is Professor of Economics, Harvard University, and Director of the Development of the American Economy Program at the National Bureau of Economic Research, where she is also Research Associate. She is the author of Understanding the Gender Gap: An Economic History of American Women (New York, I990); and co-editor, with Michael D. Bordo and Eugene N. White, of The Defining Moment: The Great Depression and the American Economy in the Twentieth Century (Chicago, 1998).

Lawrence F. Katz is Professor of Economics, Harvard University, and Research Associate of the National Bureau of Economic Research. He is editor of the Quarterly Journal of Economics; co-editor, with Robert B. Freeman, of Differences and Changes in Wage Structures (Chicago, I995).

The authors thank the Spencer Foundation for funding the collection of the Iowa State Census of I9I 5, the Russell Sage Foundation for leave support in 1997/98, and the National Science Foundation for a research grant. They also thank the research assistants who helped (C) I999 by the Massachusetts Institute of Technology and the editors of The Journal of Interdisciplinary History. 
Iowa was at the center of this belt, we use information from the unique Census of Iowa for I9I 5 at both the county and individual level to explore the factors that propelled states like Iowa to embrace so expensive a public good as secondary school education.

Our framework emphasizes both individual (private) and community (public) factors. Of the factors usually grouped under the heading of "individual," we find that income or wealth levels and the opportunity cost of education - such as the availability of manufacturing jobs for youths-were crucial to the high school expansion. But we also locate such factors as homogeneity of community, the distribution of wealth or income, and the fragmentation of social, ethnic, and religious groups that influenced how social capital aided the production of human capital. In our case study of Iowa, as well as in our evidence for the entire United States, small towns and villages experienced the highest levels, and the greatest expansion, of high school education from igio to I920. Most important was that the pecuniary returns to secondary school education were high-on the order of $\mathrm{I} 2$ percent per year. Social capital appears to have been the handmaiden of human capital, and it was more easily and rapidly accessed in areas with greater homogeneity and tightly knit communities. ${ }^{1}$

We end with a set of findings on the state-level relationship between current measures of social capital and early twentiethcentury measures of economic, educational, and social indicators. A stronger correlation exists, at the state level, between an index of social capital today (combining measures of associational activ-

to code the Iowa data, including Allegra Ivey, who collected most of the rural sample and much of the urban one, Brigit Chen, Serena Mayeri, Todd Braunstein, Misha Dewan, Michael Cress, and Arvind Krishnamurthy. The authors also thank Edward Glaesar and Caroline Minter Hoxby for illuminating discussions and the participants at the conference, "Patterns of Social Capital: Stability and Change in Comparative Perspective," Harvard University, December 4-6, I997, for useful suggestions. They are especially grateful to Robert Putnam for his social capital and educational indices.

I There are many notions of social capital. The one that we employ is similar to that in James S. Coleman, "Social Capital in the Creation of Human Capital," American Journal of Sociology, Supplement to XCIV (I988), S95-Si20. Like physical capital and human capital, social capital is a stock of productive matter that can be called upon to facilitate an action. But unlike human capital, social capital does not belong to, or inhere in, or reside in any one individual. Rather, it is part of a community, a network, a neighborhood, a country, a clan, or a family. It is more public than private; it is more social than individual. At times, it is more intangible than tangible because it exists in the relations among individuals. 
ity, social trust, and political/civic participation) and per capita taxable wealth in I9I 2 or per capita income in I900 than between the same index and per capita income in I994. A strong correlation exists between the high school graduation rate in 1928 and the index of social capital today. An equally high correlation exists between the graduation rate in 1928 and a current educational performance index (combining measures of test scores at various ages and the high school dropout rate). Social capital was not merely the handmaiden of human capital in the past; it appears to have survived many changes in the economy and society, serving a similar function today.

THE HIGH SCHOOL MOVEMENT: I9IO TO I940 The period from I9IO to I940 is often referred to as that of the "high school movement" in the United States, and the emergence of the high school as the "second great transformation" of American education. The period has been singled out as a special one in the history of education for good reason. The rise of the public high school was rapid across the entire United States. In I9Io, just 9 percent of American youths earned a high school diploma, but by 1935,40 percent did. The transition was even swifter in certain states and regions - in the three states of the Pacific region, for example, where about Io percent of youths graduated from high school in I9IO, and 60 percent by 1935 . No other country underwent the transformation to virtually universal public secondary education at so early a date. Moreover, secondary schooling was an expensive undertaking. Putting a youth through four years of high school cost the same as putting the same youth through the first eight years of common or grammar school. ${ }^{2}$

2 Martin Trow, "The Second Transformation of American Secondary Education," International Journal of Comparative Sociology, II (I96I), I44-I66, places the "high school movement" in historical perspective. For sources to the various data cited on secondary school education, see Goldin, Appendix to "How America Graduated From High School: An Exploratory Study, I910 to I960," National Bureau of Economic Research-Development of the American Economy working paper 57 (Cambridge, Mass., I994); idem, "America's Graduation from High School: The Evolution and Spread of Secondary Schools in the Twentieth Century," Journal of Economic History, LVIII (1998), 345-374. For comparative data, see Goldin and Katz, "Why the United States Led in Education: Lessons from Secondary School Expansion, I9Io to I940," National Bureau of Economic Research (NBER) working paper 6I44 (Cambridge, Mass., I997); Fritz K. Ringer, Education and Society in Modern Europe (Bloomington, 1979). On the relative cost of primary and secondary education, see, for example, U.S. Bureau of Education, Biennial Survey of Education, 1920/22 (Washington, D.C., 1924), 5. "In I91 8 the 
Because educational decisions are made primarily at a local level in the United States, the production of human capital depends largely on social capital lodged in small communities. The first tabulation of local school districts by the U.S. Office of Education in I932 set the number at c. I30,000. It was probably even higher earlier in the period. But even as late as I932 there were about 9,000 in Kansas, 7,000 in Nebraska, and 5,000 in Iowa. In I925, the states (plus the federal government) supplied just I6 percent of all educational expenditures for kindergarten through the twelfth grade $(\mathrm{K}-\mathrm{I} 2)$. States, to be sure, had powers in the educational realm besides those concerning the purse. Yet, after careful consideration, we conclude that the high school movement occurred at a grassroots level, despite the coordinating function of state governments and nationally acclaimed educators. ${ }^{3}$

The importance of the rapid move from the grammar (or common) school to that at the secondary level cannot be overemphasized. About 70 percent of the increase in years of education of the adult population from I900 to I970 was due solely to the increase in secondary school attendance and graduation. Without the rapid rise of the high school, America could not have put the G.I. Bill of Rights into immediate action after I944 because American youth would not yet have graduated high school. Nor would the I950s to I970s have witnessed the enormous expansion of college education. Although we are not prepared to claim that the rise of the United States to international economic supremacy during the period was a direct result of the greater amounts of human capital held by the average American worker, our inves-

average cost in the United States per elementary school pupil enrolled was $\$ 3$ I.65; per high-school pupil enrolled, $\$ 84.48$." The difference would have been less if weighted by states, not individuals, because states with the most support to education would have had more students in high school.

3 Not all of the I30,000 school "attendance" districts were fully independent "fiscal districts" with control over their property taxes and spending. Iowa school districts appear to have had fiscal independence. Although the counties collected school district taxes and arranged for the exchange of "tuition" payments among the state's school districts, the county appears to have been simply the fiscal agent for the districts. The districts seem to have set tax and tuition rates, within the bounds of the various state laws and regulations. On the number of school districts, see U.S. Office of Education, Biennial Survey of Education, 1930/32 (Washington, D.C., I935); U.S. Bureau of the Census, Historical Statistics of the United States: Colonial Times to 1970 (Washington, D.C., I975), series H 4I2. For data on the share of various levels of government in school finance, see U.S. Bureau of Education, Biennial Survey of Education, 1924/26 (Washington, D.C., I928), Table I8, 593. 
tigation of how important secondary schooling was to the hightech industries of the I9Io to I940 period finds that these industries took good advantage of the influx of high-school-educated youths in the labor market. ${ }^{4}$

The increased education of America's youth during the high school movement reflected a substantial commitment of the nation's resources to education. Although it is difficult, if not often inadvisable, to quantify "social capital," the commitment of resources in support of education by small communities seems one reasonable measure. Therefore, our indicator of social capital is the amount of public resources committed to education as a fraction of the total resources of the community, given by income. Figure I shows the amount spent on $\mathrm{K}-\mathrm{I} 2$ education by states and localities as a fraction of income by region and at the national level from I9Io to I930 and from I950 to I970. We omit the Great Depression and World War II years because the large income fluctuations during these periods make the series less informative.

Our indicator of educational commitment rises steeply during the I9Ios and for most of the I920s. For the United States as a whole it remains at its I930 level until the early I950s, when it rises again. In I970, the national level was about 4.5 percent, whereas it was 0.9 percent in I9I0. More than half of that increase took place from I9Io to I925. Some regions (the Pacific and the West North Central) were already committing more than 3 percent of their income to $\mathrm{K}-\mathrm{I} 2$ public education by the early I $92 \mathrm{O}$, and they also had large public higher-educational expenditures on a per capita basis. Since these regions were rich, the fraction of

4 On the role of secondary-school advances in increasing the stock of education, see Goldin, “America's Graduation from High School," Table I, 346. The World War II G.I. Bill of Rights is the subject of Keith W. Olson, The G.I. Bill, the Veterans, and the Colleges (Lexington, Ky., I974) which, on the basis of a simple extrapolation, concludes that the bill had a negligible net impact on the number of men who went to college. Marcus Stanley, "The Impact of the World War II G.I. Bill on the College Graduation of Men," unpub. paper, Harvard University (Cambridge, Mass., 1997), using more sophisticated tools and cohort-specific data, finds that the bill increased the numbers of men graduating from college in the affected cohorts (born I92 I to I927). Other possible effects of the G.I. Bill, for example the distribution of college students across universities, have not yet been examined thoroughly.

On the use of high school graduates by industry, see Goldin and Katz, "The Origins of Technology-Skill Complementarity,” Quarterly Journal of Economics, CXIII (I998), 693-732. 
Fig. 1 State and Local Elementary and Secondary Educational Expenditures as a Fraction of Regional Income or U.S. Personal Income

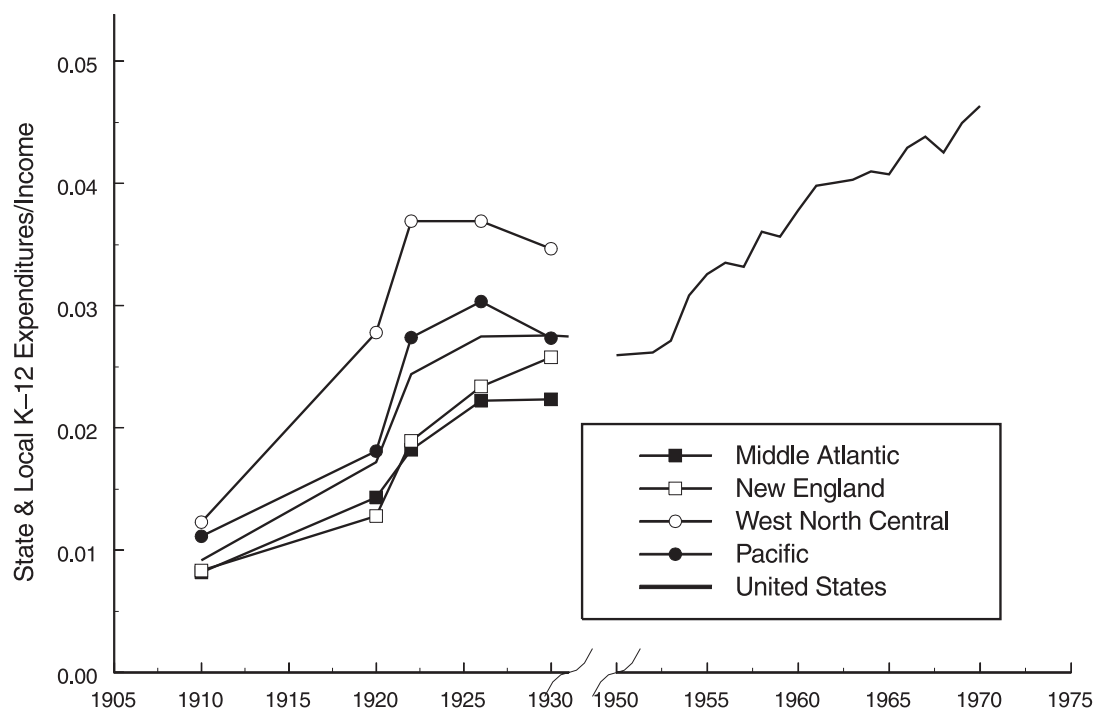

NOTES The periods of the Depression and World War II are omitted because of large changes in the denominator-income. Although the income measures for 1910, 1920, and I929 differ from that for the post-I950 period, the national number for 1929, derived from the state figures, is close to that in the national series used for the post-I950s. State income and population figures for 1922 and 1926 were interpolated from the data for 1920 and 1930 (I929 for the income data). Population figures were necessitated because the I920 and I929 income data are per capita. The $\mathrm{K}-\mathrm{I} 2$ expenditure data include current expenses and "outlays, new buildings, sites and new equipment" for public day schools. The data used to construct the regional data for I9Io to I930, by separate states, contain virtually the same U.S. totals as in U.S. Bureau of the Census, Historical Statistics, series H 492, used for the post-I95os national series.

SOURCES For K-I2 expenditures, I920, I922, I926, and I930, see U.S. Bureau (or Office) of Education, Biennial Survey of Education [for year] (Washington, D.C., [year]). For post-I950, see U.S. Bureau of the Census, Historical Statistics of the United States (Washington, D.C., I975), series H 492. For income in I920, see Simon Kuznets, Ann Ratner Miller, and Richard A. Easterlin, Population Redistribution and Economic Growth: United States, 1870-1950. II. Analyses of Economic Change (Philadelphia, I960); for I929, U.S. Department of Commerce, Bureau of Economic Analysis, State Personal Income by State Estimates for 1929-1982 (Washington, D.C., I984); for post-I950 population, U.S. Bureau of the Census, Historical Statistics, series F 8, personal income. For I9IO and I920, see U.S. Bureau of the Census, Historical Statistics, series A 195 . 
their income devoted to education represented an impressive absolute amount. ${ }^{5}$

The U.S. Bureau of Education explained the substantial increase in educational expenditures just after World War I by several factors: The war both unified and intensified the increase in educational expenditures throughout the country, plainly demonstrating to communities that they harbored poorly educated, illiterate, and physically unfit Americans. But in many sections of America, the single most important change that affected how much money went to education was the increase in high school attendance; each student year of upper grades cost about twice that of the lower grades. Furthermore, the length of the school year generally increased, as did the real cost of teacher's salaries in many parts of the country. The upshot of all of these factors was a cost of education that was escalating at a rate faster than that of income. $^{6}$

What is most important about the history of the American high school in this context is that the modern version-one that we would easily recognize today-emerged c. I9Io. Prior to I900, secondary schools in much of America often trained youths to gain entry to particular colleges and universities in their vicinity. During the period of the high school movement, however, secondary education was transformed into training "for life," rather than "for college." In I9I0, 49 percent of high school graduates continued to some form of higher education; by 1933, only 25 percent did. Secondary schools were granting more terminal degrees, not because college entry had declined but because high school entry had so greatly increased. ${ }^{7}$

5 For an analysis of public expenditures on higher education per capita, see Goldin and Katz, "The Origins of State-Level Differences in the Provision of Higher Education: I 890 to I940," American Economic Review, LXXXVIII (1998), 303-308. See also Fred J. Kelly and John H. McNeely, The State and Higher Education: Phases of Their Relationship (New York, I933), 257. Of the top fourteen states in 1930 by "receipts from state, county, or city of publicly supported higher education per [non-black] inhabitant 2I years of age and over," all but six are in the Pacific or West North Central regions and four of the six are in the Mountain region. One of the remaining two is South Carolina, because Kelly and McNeely exclude blacks from the denominator. The other is Oklahoma.

6 See the lengthy discussion in U.S. Bureau of Education, Biennial Survey, 1920/22, I-9, on the increase in educational expenditures directly following World War I.

7 Our contributions to the literature on high schools include Goldin, "America's Graduation from High School"; idem and Katz, "Why the United States Led." Among the most-cited volumes are Edward A. Krug, The Shaping of the American High School: 1880-1920 (Madison, I964); idem, The Shaping of the American High School: 1920-1941 (Madison, I972), II; William 
What were the reasons for the large influx of students into American high schools, and why did local government respond by building schools and staffing classes? Education at the secondary level is distinctive for being almost always publicly funded and supplied, both in the United States and elsewhere. Yet, it has almost none of the features of a public good and many of the characteristics of a private good. The relevant issue is one of timing rather than degree, since all communities in the United States, and most countries in the world, have undertaken public funding of secondary-school education at some point. Hence, the question is, Why did secondary schools diffuse so rapidly during this particular period? ${ }^{8}$

In nineteenth-century America, the high school had been attacked as an "elitist" institution. Local taxpayers were often united against its funding on the grounds that it would serve only a small and wealthy clientele who could afford to send their sons and daughters to college. Such debates continued across America as the high school movement spread. The funding of many early high schools, particularly outside major cities, was justified as a strengthening of the common-school system; high schools, after all, trained teachers for the lower grades. This argument, however, saw little use during the high school movement. Also rare was the argument that schools produced the literate populace necessary to maintain a great democracy; it was offered in behalf of the common-school revival, not the high school movement. The reasons given for championing secondary education were more mundane. ${ }^{9}$

J. Reese, The Origins of the American High School (New Haven, I995). In the current article, we pay less attention to the special subject of secondary schooling in America's big cities than we have done in previous work. These issues have been the focus of many fine works, among them David Tyack, The One Best System (Cambridge, Mass., I974); David F. Labaree, The Making of an American High School: The Credentials Market and the Central High School of Philadelphia, 1838-1939 (New Haven, I988); Joel Perlmann, Ethnic Differences: Schooling and Social Structure among the Irish, Italians, Jews, and Blacks in an American City, 1880-1935 (New York, I988). For data on the numbers of secondary-school graduates continuing to higher education, see Goldin, "America's Graduation from High School," Table 2, 35 I.

8 In this manner, the question we ask is similar to that in work on the diffusion of technological processes. See, for example, Zvi Griliches, "Hybrid Corn: An Exploration in the Economics of Technological Change," Econometrica, XXVI (I958), 50I-522.

9 Michael B. Katz, The Irony of Early School Reform: Educational Innovation in Mid-Nineteenth Century Massachusetts (Cambridge, Mass., I968), and Maris A. Vinovskis, The Origins of Public High Schools: A Reexamination of the Beverly High School Controversy (Madison, I985), have 
The first and foremost among them was the expected financial return to high school students c. I9Io, even in the absence of a college education. But because the I940 U.S. population census was the first to ask questions about education and earnings, concrete evidence in support of this claim has not been easy to locate. Elsewhere we have shown that, from I 890 to I920, occupations common to high school graduates (for example, such ordinary white-collar workers as secretaries, bookkeepers, and typists) paid twice the monetary amount as did occupations that tended to employ individuals without high school training. In this study, we are able to estimate, more directly, the returns to years of schooling by using the manuscripts of the Iowa State Census of I9I 5 - a unique document both for its time and for many years to come because of its information on education and earnings, among other variables. These data reveal that the financial return on high school in I9I 5 was substantial, on the order of 12 percent for each year completed. State school superintendents used such arguments to recommend new high schools and teachers. As the epigraph suggests, they also maintained that schools were good investments for property owners: If high schools were good for youths, they were also good for property owners in school districts that had them. ${ }^{10}$

Community cohesion was also a prominent rationale for the building and funding of high schools and for the consolidation of

different interpretations of the opposition of one community to the building of a high school. Katz sees the opposition based on class, whereas Vinovskis interprets it more pragmatically as a matter of which individuals lived closer to the proposed school. Early controversy about state and local financing of high schools is also taken up in Reese, Origins. See also Isaac Leon Kandel, History of Secondary Education: A Study in the Development of Liberal Education (Boston, I930), particularly on the important Kalamazoo case of I 874, after which states no longer questioned whether localities had the authority to tax citizens to establish a high school. Kalamazoo thereby served to legalize the spread of the public high school in America by attaching its importance to that of the common school. For a discussion of the establishment of early high schools in Iowa to produce teachers for the common school system, see Clarence Ray Aurner, History of Education in Iowa (Iowa City, I9I5), I, III. Although the early high schools charged tuition, through the "rate bill," individuals who promised to teach received a tuition waiver. As early as I 858 , Iowa offered scholarships and stipends to students in the top half of their high school class, provided that they became teachers and served for the length of time that they had received the scholarship (I, 52-53).

Io For data on the wage structure by occupation, see Goldin and Katz, "The Decline of Noncompeting Groups: Changes in the Premium to Education, I 890 to I940," NBER working paper 5202 (Cambridge, Mass., I995). 
small districts. Proponents warned about the possibility of migration from communities that did not provide adequate schooling. So important was the provision of secondary schooling to the children of rural America that youths often went to live with relatives in towns and cities when their local district did not provide such education, and sometimes entire families moved to the closest town when their oldest child graduated from the local common school. Hence, one good reason for building schools in rural America was "to stop the drift of the population to the cities." 11

The second appeal in the epigraph concerns a pivotal factor in the expansion of public high schools. If the creation of a literate citizenry was not a good enough reason for publicly funded secondary schooling, the justification had to come from another market failure or externality - the inability of the capital market alone to effect the optimal transfer of resources both within and between generations. Communities composed of different generations, however, could solve this problem. First, the established members of the community could lend to young parents during the most stressful portion of their economic life cycle, when they are not yet at their peak earning capacity. Then, this generation could pay back the loan when it, in turn, became the next older generation. Selling that logic to a current older generation also meant selling the idea that an educated community conferred positive externalities as a place where the aged could depend on their neighbors. With this reasoning, the older generation would be convinced to buy into the plan, and the younger generation would not defect as it aged. ${ }^{12}$

Two points are important to make at this juncture. One is that a vibrant and self-replicating community was a blessing to older residents, especially in areas with long harsh winters. Another is that just because good schools induced some young people and families to stay put does not mean that extensive out-migrations did not flow from these areas. In many of the states of the

\footnotetext{
I I State of Iowa, Iowa School Report, 1911/12 (Des Moines, I9I2), I2. In Willa Cather's novel, My Antonia (Boston, I9I8), which takes place in south-central Nebraska in the I890s, Jim Burden's grandparents retire from farming and move to town so that he can attend the local high school.

I2 For a similar argument see Gary S. Becker and Kevin M. Murphy, "The Family and the State," Journal of Law and Economics, XXXI (I988), I-I8.
} 
Great Plains, for example, education was not just good for the existing community; it was also good for those who wanted to leave the region and give up farming.

A FRAMEWORK OF HIGH SCHOOL EXPANSION: PUBLIC AND PRIVATE CONCERNS Attendance at, and graduation from, high school was considered beneficial to individuals and families because of its potential private returns. But communities were crucial; they, and only they, could provide the means by which all children could attend secondary school. Our implicit model of the expansion of high schools concerns both decision-making bodies.

At the family or individual level, consider the private decision of investing in education in a two-period framework. In period $\mathrm{I}$, the individual earns a wage of $w_{\mathrm{I}}$ and does not attend school; in period 2, the same individual earns a wage of $w_{2}$. Alternatively, the individual can attend school in period I, pay $C$ in direct costs (for example, tuition, transportation, and books), and earn nothing. In period 2 , however, the individual with schooling earns $E_{2}>w_{2}$. Given a one-period discount rate of $r$, the decision to attend school in period I depends on whether

$$
\frac{\frac{E_{2}}{w_{2}}-\mathrm{I}}{\mathrm{I}+r}>\frac{C+w_{1}}{w_{2}},
$$

which simply means that the individual will go to school if the discounted returns to education (left side) exceed the first-period costs (right side). ${ }^{13}$

The simple framework leads us to consider the high school wage premium $\left(E_{2} / w_{2}\right)$, the costs of education (direct, $C / w_{2}$, and indirect, $\left.w_{1} / w_{2}\right)$, and the discount rate $(r)$, which is a measure of capital-market constraints facing individuals and families, as they affect the private demand for education. High school enrollment decisions are positively affected by the high school wage premium and negatively affected by the costs of education and the discount rate. The private demand for high school is also likely to depend positively on family wealth (or income) through an income effect on the consumption demand for education and by the easing of 
capital-market constraints (that is, increased wealth effectively lowers $r$ ).

But this simple human-capital framework says nothing about one of the most obvious facts of education-its almost-ubiquitous public provision. Why do communities at the local, state, and national levels tax their citizens to provide education for other people's children? Public funding was part of an intergenerational loan. According to this view, homogeneous communities, in which people tend to remain and take an active interest in each other, would be more likely to provide intergenerational loans. In a manner similar to Coleman's notion of "closure," the degree to which community members saw themselves as part of a generational succession would determine their support for the high school, especially during its formative years. ${ }^{14}$

On the other hand, communities in which wealth or income was unequally distributed would encounter substantial opposition to the high school movement. Because schooling is a private good and because, before the I930s, few legal constraints were in place to compel youths to attend high school, those at the bottom of the distribution could opt out entirely. Those at the top of the distribution might have opted out by attending private schools. Thus, the wider the distribution of income, the greater was the chance of encountering a political equilibrium in which the poor and the rich joined to defeat the public provision of a high school; such an equilibrium is aptly termed "the ends against the middle." 15

I4 By "closure" Coleman means the results of any mechanism that links social relationships to facilitate the drawing on social capital. For example, assume that school children do better when their parents take an interest in them and that parents are "shamed" when others see that they do not do homework with their children. Closure may be facilitated when parents get together and discuss how to help their children with homework. The parental meeting is a "social structure that facilitates social capital" (Coleman, "Social Capital in the Creation of Human Capital," Sio5). See also Coleman, Foundations of Social Theory (Cambridge, Mass., I990), chap. I2, 300-32I.

I5 In 1917, for example, although thirty states had a maximum age of sixteen years for compulsory schooling, all but four granted labor permits at, or before, age fourteen, and the remaining four granted them at age fifteen. The education required for a labor permit was nowhere more than eight years and exactly eight years in just five states. In I928, the maximum age of compulsory schooling had increased to eighteen in five states and to seventeen in another five states. But labor permits were still issued to those under sixteen in all but two states, and the education required for a labor permit was nowhere greater than eight years. The laws do not appear to have constrained youths to remain in high school, let alone to have graduated from high school. See Ward W. Keesecker, Laws Relating to 
The "social capital" needed to produce human capital is a function of factors that create "closure," binding generations to each other and creating a belief that educated youth will later benefit older community members. Recent work has shown that communities fragmented by ethnicity or language or comprised of persons who migrated to the community in their older age tend to be less supportive of educational expenditures. In our empirical work, we use proxies for these variables: the fraction foreign born, the fraction Catholic, the fraction older than sixtyfive years, and the distribution of wealth, itself proxied by another variable. ${ }^{16}$

Our exploration of the factors influencing high school expansion takes place at four levels of aggregation. First, at the national level, we look at variation in high school graduation rates for a cross section of states, and in attendance rates across different-sized cities and towns. We then focus on Iowa-a leading state in the high school movement-first at the county level and then at the family and individual level, using the Iowa State Census of I9I5.

FACTORS INFLUENCING HIGH SCHOOL EXPANSION AT THE STATE LEVEL Figure 2 graphs the percentage of youths in various regions of the United States who graduated from high school in the year given. The contemporaneous graduation rate is a "cleaner" variable than enrollment or attendance, in the sense that it permits less ambiguity in its meaning. Because we summarize our previous work in this section, we do not give data on all

Compulsory Education (Washington, D.C., 1929). See Dennis Epple and Richard E. Romano, "Ends Against the Middle: Determining Public Service Provision When There Are Private Alternatives," Journal of Public Economics, LXII (I996), 297-326, and Raquel Fernandez and Richard Rogerson, "On the Political Economy of Education Subsidies," Review of Economic Studies, LXII (1995), 249-262, for the role of income distribution in public-choice models of education.

I6 James Poterba, "Demographic Structure and the Political Economy of Public Education," Journal of Policy Analysis and Management, XVI (I997), 48-66, finds that the greater the growth in the proportion of older people in U.S. states from I96I to I99I, the lower was the growth in funding for K-I2 education. Alberto Alesina, Reza Baqir, and William Easterly, "Public Goods and Ethnic Divisions," NBER working paper 6007 (Cambridge, Mass., I997), finds a negative relationship between ethnic fractionalization and spending on "productive" public goods, including education, in a cross section of U.S. localities c. I990. 
Fig. 2 Public and Private High School Graduation Rates for Four Regions, I910 to I958

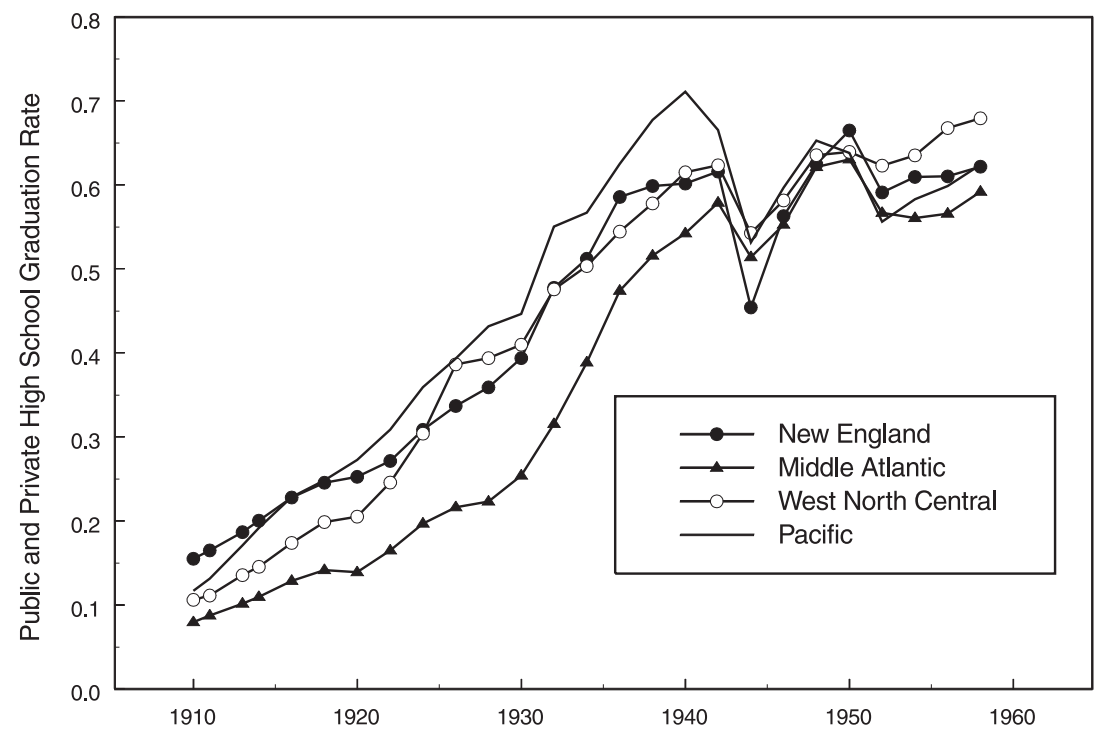

NOTES The public and private high school graduation rate is the number of individuals graduating from high school in a state (summed to the regional level) divided by the number of seventeen-year-olds in a particular year. Graduation from high school includes those in public, private nonsectarian, and private-denominational schools, as well as individuals in the preparatory departments of colleges and universities.

SOURCES See Goldin, Appendix to "How America Graduated from High School: An Exploratory Study, I9Io to I960," National Bureau of Economic Research-Development of the American Economy working paper 57 (Cambridge, Mass., I994) for details concerning the construction of the series.

regions in Figure 2. Rather, the figure shows the regions that included many of the leading states (New England, West North Central, and Pacific) and one region containing some of the nonsouthern laggards (Middle Atlantic). Although New England led the country in the proportion of its youth passing through secondary schools in I9I0, it was soon eclipsed by many of the states in the West. By the mid-I920s, more than 40 percent of youths in the Pacific states were graduating from high school. Other leading states in the high school movement were those in the nation's heartland-prominent among them being Iowa, Kansas, and Nebraska. The states of the Middle Atlantic closed much 
of their gap with the leading states in the I930s, when the Depression shut down the employment route for many youths. ${ }^{17}$

The maps of Figure 3 tell much the same story but highlight various areas of the country that figure prominently in our later discussion. In I9 Iо, the darkest areas of the map, those with the highest rates of high school graduation, were in New England, although some were scattered in the mid-section of the nation. But by I928, the highest graduation rates occurred clear across the mid-section of the United States, in "the education belt," stretching from the Pacific states through Utah, Colorado, Nebraska, Kansas, Iowa, Indiana, and then jumping to New England. The southern states, it is no surprise, lagged. Although we do not show this information in the graph, the South was behind in all periods of the high school movement, not simply because blacks were less educated; high school graduation rates for southern white youths were also below the nation's.

In a previous study, we analyzed the factors that encouraged high school graduation, attempting to explain why certain parts of the country led in the high school movement whereas others did not. We employed both state-level data at various points in time from I9Io to I938, and city-level data in I9IO, I920, and I930. In the state-level analysis, we looked at a series of cross sections, as well as at changes from I9IO to I928 and 1928 to I938. Some of the analysis is reproduced in Table I. ${ }^{18}$

In keeping with the framework just discussed, our explanatory variables can be divided into two main types, the variables

I7 Graduation rates are "cleaner" in the sense that most states accredited high schools and set standards for graduation, whereas enrollment rates could have been overstated for many reasons, including the state's method of funding local education. Some ambiguity remains, however, with regard to the quality of education and how it changed over time. The graduation rate is equal to the number of high school graduates (including those from private schools and the preparatory departments of colleges and universities) divided by the number of seventeen-year-olds in a given state during a particular year. It should be noted that the data in figures I and 2 are described in detail in Goldin, "Appendix," and were assembled from state-level data on public high schools, private high schools, and the preparatory departments of universities and colleges. Although they did not originate in the national graduation data given, for example, in U.S. Bureau of the Census, Historical Statistics, they track those national totals well. In all cases, they are contemporaneous data reflecting graduation from high school at a point in time and as a fraction of the youths in a state. I 8 We have also estimated longitudinal models with state fixed-effects pooling data from I910, I920, and 1930. The results for the key variables are similar to those in the levels regressions presented in Table I. But the effects of some variables (for example, percentage Catholic and manufacturing employment share) cannot be estimated precisely when state 
Fig. 3 Public and Private High School Graduation Rates by State, I9Io and 1928
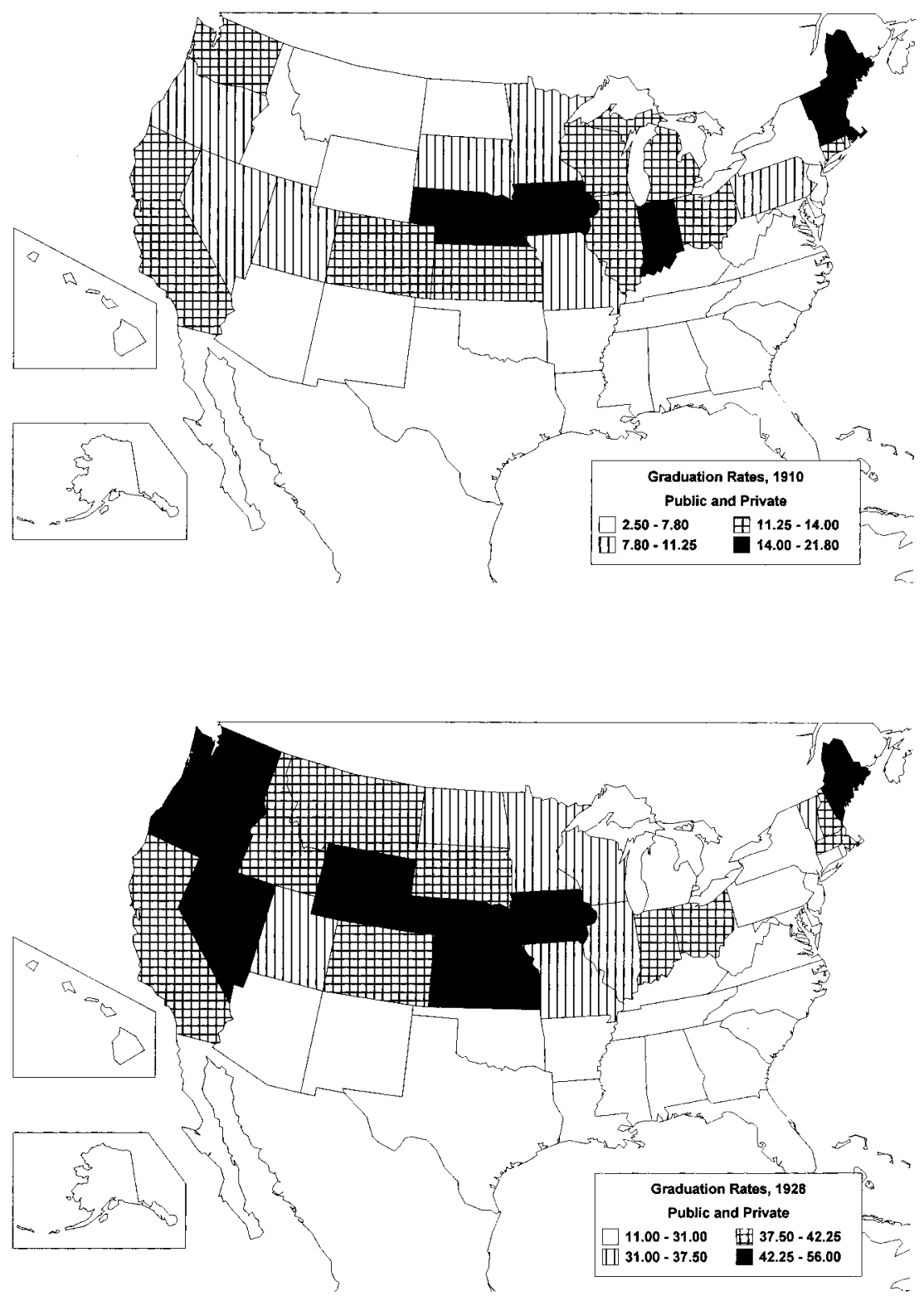

NOTES See Figure 2. The shadings of the two maps allow an equal number of states to fall into each of the three shaded categories for the two years. 
that influence the individual, or private, choice of education and the variables that affect the public, or social, choice of group action. Put another way, certain variables alter whether individuals invest in human capital, and certain others indicate whether social capital is available for the same investments. Some of the variables can be located in both arenas, though many are more clearly in one and not the other.

Table I presents cross-section regressions for I9IO and I928, as well as a regression to explain the change in high school graduation rates from I9IO to I928 as a function of initial conditions of states at the start of the high school movement in I9Io. Because the regressions are cross-state, there are only forty-eight observations, and many of the variables of potential interest are collinear. The fraction Catholic, for example, is highly correlated both with the fractions foreign-born and urban; per capita income is similarly collinear with wealth per capita and agricultural income per farm worker. We have, therefore, chosen a set of variables that can stand in for many others.

In both I9I0 and I928, the high school graduation rate was positively related to various measures of wealth (or income) and negatively related to the opportunity cost of education (as proxied by the percentage of the labor force in manufacturing and the wage of manufacturing workers). Because educated labor was highly mobile, the wage relevant for those deciding whether to attend high school exhibited little cross-state variation. Hence, we do not include a measure of white-collar wages in the regressions. Yet, we find that states where a larger fraction of youth attended public colleges and universities in I9IO experienced faster growth in high school graduation rates from I9IO to 1928. Greater access to public universities is likely to have increased the private returns to high school, and it may also have been a reflection of the commitment of state residents to public education in general. Greater wealth in I9Io also hastened the growth of high schools from I9IO to I928, whereas a larger share of manufacturing employment in I9Io modestly retarded it.

fixed effects are included, and coefficients are constrained to be constant over time, because of the strong persistence of state differences in these variables. For details, see Goldin and Katz, "Why the United States Led." 
Table 1 Explaining Total (Public and Private) Secondary-School Graduation Rates by States, I9IO and I928

\begin{tabular}{|c|c|c|c|}
\hline & (I) & (2) & (3) \\
\hline & I9IO & 1928 & I928-I9IO \\
\hline Log per capita wealth, I9I 2 or $1922, \times \mathrm{IO}^{-\mathrm{I}}$ & $\begin{array}{l}0.236 \\
(0.090 \mathrm{I})\end{array}$ & $\begin{array}{l}0.852 \\
(0.368)\end{array}$ & $\begin{array}{l}0.857 \\
(0.260)\end{array}$ \\
\hline Fraction $\geq 65$ years, I9Io or 1930 & $\begin{array}{l}2.13 \\
(0.260)\end{array}$ & $\begin{array}{c}\text { I. } 423 \\
(0.788)\end{array}$ & $\begin{array}{c}-\mathrm{I} .749 \\
(0.737)\end{array}$ \\
\hline $\begin{array}{l}\text { Fraction of labor force in manufacturing, } \\
\text { I9I0 or } 1930\end{array}$ & $\begin{array}{c}-0.0673 \\
(0.0335)\end{array}$ & $\begin{array}{l}-0.144 \\
(0.0972)\end{array}$ & $\begin{array}{c}-0.0495 \\
(0.0947)\end{array}$ \\
\hline Fraction Catholic, I910 or 1926 & $\begin{array}{c}-0.0913 \\
(0.0305)\end{array}$ & $\begin{array}{l}-0.377 \\
(0.0867)\end{array}$ & $\begin{array}{l}-0.265 \\
(0.0900)\end{array}$ \\
\hline South & $\begin{array}{l}-0.0449 \\
(0.00932)\end{array}$ & $\begin{array}{c}-0.0935 \\
(0.0272)\end{array}$ & $\begin{array}{c}-0.0735 \\
(0.0267)\end{array}$ \\
\hline New England & $\begin{array}{l}0.0444 \\
(0.012 \mathrm{I})\end{array}$ & $\begin{array}{l}0.100 \\
(0.0310)\end{array}$ & $\begin{array}{c}0.08 \text { I I } \\
(0.0333)\end{array}$ \\
\hline Males in public colleges/I7-year-olds, I9IO & & & $\begin{array}{l}\text { I.09 } \\
(0.384)\end{array}$ \\
\hline Auto registrations per capita, I930, $\times$ IO & & $\begin{array}{c}0.0568 \\
(0.0230)\end{array}$ & \\
\hline Constant & $\begin{array}{l}-0.136 \\
(0.0709)\end{array}$ & $\begin{array}{c}-0.468 \\
(0.273)\end{array}$ & $\begin{array}{c}-0.324 \\
(0.199)\end{array}$ \\
\hline$R^{2}$ & 0.895 & 0.874 & 0.758 \\
\hline Root mean-squared error & 0.0172 & $0.045 \mathrm{I}$ & 0.0474 \\
\hline Mean (unweighted) of dependent variable & 0.0882 & $0.29 \mathrm{I}$ & $0.2 \mathrm{I} 2$ \\
\hline
\end{tabular}

NOTES Standard errors are in parentheses; ordinary least-squares regressions, unweighted. Weighting by state population does not substantially affect the results. Number of observations is forty-eight for all regressions; the District of Columbia is not included. Arizona and New Mexico were territories until I9I2 but are included in the data for I9IO states. The dependent variable in column (3) is the change in the total (public and private) high school graduation rate from I9IO to I928; the independent variables in column (3) are measured in I9IO or the closest year possible.

SOURCES For dependent variable, total (public and private) graduation rate by state, see Goldin, Appendix to "How America Graduated from High School: An Exploratory Study, I910-I960," National Bureau of Economic Research-Development of the American Economy working paper 57 (Cambridge, Mass., I994). Graduation rate divides by seventeen-yearolds in the state. Unweighted means of the independent variables are given in parentheses. For per capita wealth, I9I2 $(\$ 1,934)$ or I922 $(\$ 2,966)$, taxable wealth/population data come from U.S. Department of Commerce, Statistical Abstract of the United States (Washington, D.C., I925). For fraction $\geq 65$ years, I9Io (.04I4), or I930 (.055), see U.S. Bureau of the Census, Historical Statistics (Washington, D.C., I975), 195-209. For fraction in labor force manufacturing, I9I0 (.248), or I930 (.254), see U.S. Bureau of the Census, Thirteenth Census of the United States: 1910, Population (Washington, D.C., I9I2); U.S. Bureau of the Census, Fifteenth Census of the United States: 1930, Population (Washington, D.C., I932), III. For fraction Catholic, I9Io (.I 50), or 1926 (.I 5I), see U.S. Department of Commerce, Religious Bodies: 1926 (Washington, D.C., I930), I, Table 29. The I9Io numbers are derived from those of I906 and I9I6. All are expressed per state resident. South (0.354) includes the census divisions South Atlantic, East South Central, and West South Central. New England (0.125) is the census division of New England. For males in public colleges/I7-year-olds, I9Io (.03 I6), see U.S. Department of the Interior, Report of the Commissioner of Education (Washington, D.C., I9I0), Table 3I, 850. Military academies receiving public support are excluded. Since the denominator includes both males and females, it is about equal to half the eighteen-totwenty-one-year-old group of males. For auto registrations per capita, I930 (0.224), see U.S. Bureau of Commerce, Statistical Abstract of the United States (Washington, D.C., I940), Table 467. 
Of most importance for the issues raised in this study, high school graduation is positively related to the proportion of the state's population over sixty-four-years old and negatively related to the proportion Catholic in both I9IO and I928. In the 1928 regression, we also include a variable that captures important aspects of both the level and distribution of wealth. Since automobile registrations per capita in 1930 provide a count of those rich enough to afford a car, automobile registrations per capita summarizes mean wealth and its distribution in a form particularly relevant for decisions about the provision of a public good. It proxies the share of voters likely to favor financing so expensive a public good as high schools. At a high enough level of mean wealth, high automobile registrations per capita are likely to indicate a more equal distribution of wealth. No other variable has as large an effect on the high school graduation rate in the late I920s and early I930s as does automobile registrations per capita. The states with the highest in I930-California, Nevada, Kansas, Nebraska, and Iowa-were also leaders in the expansion of high schools, as shown in the bottom panel of Figure 3. The strong positive effect of automobile registrations per capita on high school graduation rates in I928, as shown in column (2) of Table I, is apparent, even when state mean per capita wealth is also included as a regressor.

The distribution of wealth is an important input to the political and social decisions to fund high schools. Stability and homogeneity of community, as well as many of the more familiar and better-understood variables thought to affect human capital decisions, were important in the diffusion of the high school across America during the period of the high school movement. The state-level analysis points to many of the public and private factors that propelled the high school movement and reveals the types of states that led in secondary education. Because many of the leading states were rich agricultural areas, they were also thickly dotted with small towns and villages that served the agricultural hinterland. The high school movement appears to have found its greatest support in these small towns and villages.

Table 2 gives the full-time school attendance of sixteen- and seventeen-year-olds by size and type of place for I9IO and 1920 in all nonsouthern states. The attendance rates in the smallest towns were more than double those in the largest cities in I9Io, 
Table 2 "Full Time" School Attendance Rates for Sixteen- and Seventeen-Year-Olds: U.S. Non-South, by Size and Type of Place, I9Io and I920

\begin{tabular}{|c|c|c|}
\hline SIZE AND TYPE OF PLACE & I9IO $(\%)$ & I920 (\%) \\
\hline $\begin{array}{l}\text { Rural (unincorporated or }<\text { I, OOO population) } \\
\text { unincorporated } \\
\text { incorporated and }<\text { I,O0o population }\end{array}$ & $\begin{array}{l}37.7 \\
36.3 \\
48.1\end{array}$ & $\begin{array}{l}38.7 \\
-\mathrm{a} \\
-\mathrm{a}\end{array}$ \\
\hline Town (I,O00 < IO,o00 population) & 40.5 & 43.9 \\
\hline $\mathrm{I}, \mathrm{OOO}<2,500$ population & 45.7 & $47 \cdot 3$ \\
\hline $2,500<$ I0,000 population & 37.7 & 42.0 \\
\hline Small city (I0,000 $<25$, 000 population) & 36.9 & $35 . \mathrm{I}$ \\
\hline City (> 25,000 population) & 26.I & $3 \mathrm{I} .7$ \\
\hline $25,000<$ I00,000 population & $3 \mathrm{I} .5$ & 35.9 \\
\hline IOO,O00 $<500,000$ population & 28.8 & 33.8 \\
\hline$\geq_{500,000}$ population & $2 \mathrm{I} .3$ & 28.2 \\
\hline Number of observations & 9,607 & II,955 \\
\hline
\end{tabular}

a The 1920 data do not separate the unincorporated areas from the small incorporated villages. NOTES "Full time" school attendance means that the youth attended school at some point after September I of the previous year and was not currently working during the census year (that is, no occupation was given in the census). The pattern of results displayed in this table for both I9IO and I920 are similar (but modestly attenuated) in logit models or linear regressions of full-time school attendance on a full set of indicator variables for size of place, as well as in detailed controls for race, foreign-born status, parents' foreign-born status, household head's occupation, and region.

sources I9io Public Use Micro-data Sample (pums) of the U.S. federal population census of I9IO; I920 Integrated Public Use Micro-data Sample (IPUMS) of the U.S. federal population census of 1920 .

and, in both years, attendance rates declined monotonically as the size of place increased for incorporated areas. Even the unincorporated rural places of the United States, which were mainly farming areas of the open country, had higher attendance rates than did the larger cities. The site of the early high school movement appears to be those small communities in which social capital may have been the greatest. That many of the leading states in the high school movement through the early I930s-such as Nebraska, Kansas, South Dakota, and Iowa-were also those that had large numbers of school districts relative to population (few people per school district) further indicates that the decisions made by small, wealthy, homogeneous communities facilitated expensive collective investments in high schools. We will return to the role of the small town in our analysis of the Iowa data. ${ }^{19}$

\footnotetext{
I9 "Full time" attendance means that the youth attended school for at least one day since September I in the previous year and did not list an occupation. We include only nonsouthern states to avoid conflating rural and small town with the South in the simple cross tabulations. The attendance data in Table 2 probably overstate the proportion of youths in secondary
} 
SECONDARY SCHOOLING IN THE HEARTLAND: CASE STUDY OF IOWA, I9I5 Iowa was both an early leader in the high school movement and part of the education belt that formed in the I920s. It was also among the richest states in the union on a per capita basis in both I9I2 and I922. In I9I 2, it ranked second, behind Nevada, and in I922, fourth, behind Nevada, Wyoming, and South Dakota in per capita taxable wealth. It pioneered in the standardized testing of its youth, had a widespread system of private colleges and universities, established leading research centers in its public universities, and was the birthplace of agricultural extension in America. In the early twentieth century, Iowans wanted to make the superiority of their educational system known to the rest of the country and prove that their state was just as respectable as those of the northeast, from which many of their ancestors had come. $^{20}$

With its I9I5 population census, Iowa became the first state to request information from its citizens about their educational attainment and current school attendance. The responses, not surprisingly, allowed the state proudly to note that "for the first time there has been secured information showing the extent of education of the entire population and the results confirm the

schools, because the U.S. federal population censuses of I9IO and I920 inquired whether an individual had attended school at least one day during the preceding year. Attendance could have been at a night, correspondence, industrial, music, commercial, private, parochial, or regular-day school, among others. Furthermore, many young people, especially in the open country, could have been attending common schools at age I6 and I7, not state-accredited high schools. Margaret E. Greene and Jerry A. Jacobs, "Urban Enrollments and the Growth of Schooling: Evidence from the U.S. I9ro Census Public Use Sample," American Journal of Education, CI (I992), 29-59, report similar results for I9Io, regarding the role of small towns. The cross-state correlation of school districts per capita in 1932 and the high school graduation rate in 1928 is 0.49 . This significant positive relationship between the density of school districts and high graduation rates remains in high school graduation regressions that control for population density or the urban share of the population. It is apparent even when examining only states outside the South. But the number of school districts per capita is closely related to wealth, automobile registrations per capita, and agricultural income per farm worker; it is not statistically significant in such regressions that include proxies for wealth.

20 On per capita wealth data, see the sources in Table I; Goldin and Katz, "Why the United States Led."

The city of Des Moines used its local commercial magazine, Des Moines Wealth, to broadcast the superiority of its school system in comparison with all others in the United States. "Des Moines therefore equals all and excels most cities in . . school attendance in proportion to population, high school enrollment, number of teachers in proportion to the size of the school system, and salaries paid to the teachers. . . . Des Moines is recognized the country over as a grand school city" (Des Moines Wealth, II [June I9Io], I 5 ). 
general belief that Iowa people rank very high in educational matters." 21

The Iowa state census of I9I5, like most other censuses, was a Ioo percent sample of the citizens of the state. The volume, Census of Iowa, 1915, contains detailed tables that highlight aspects of the population by county. Its manuscript census, which consists of one three-by-five index card per person, has been filed by county, arranged alphabetically by last name. In I986, the Church of Jesus Christ of Latter-day Saints microfilmed all the cards. Several researchers have collected samples from this unique census, but because of the idiosyncratic nature of these data sets, we have collected our own. Ours is a cluster sample of three large cities (Davenport, Des Moines, and Dubuque) and eight "rural" counties. Several medium-sized cities are also in our "rural" sample, as are a large number of smaller towns and villages. We have also assembled a county-level data set from the Iowa state census of I9I 5 and various federal censuses. ${ }^{22}$

Even though schooling rates were high in Iowa, the percentage of teenagers who currently attend high school and who ever attended high school show considerable variation across the state. Across Iowa's ninety-nine counties in I9I4, the proportion of ten-to-twenty-year-olds with any high school ranged from o.I I to $0.3 \mathrm{I}$, and the proportion of ten-to-eighteen-year-olds currently attending high school varied from 0.086 to 0.32. In I9I4, high school enrollment rates (measured by the ratio of students in high schools to the population aged fourteen to seventeen years) by region ranged from a low of O.I43 in the South Atlantic to a high of $0.35 \mathrm{I}$ in New England. Thus, Iowa's counties spanned a range similar to that of all regions at the same time. To understand the reasons why communities did, or did not, invest in high schools during the early period of the high school movement, we first

2 I State of Iowa, Iowa State Census, 1915 (Des Moines, I9I6), xxxvi. Only one other state (South Dakota in I9I5) asked about educational attainment before the federal population census did in 1940. Iowa repeated the question in its 1925 state census.

22 Richard Jensen and Mark Friedberger, "Education and Social Structure: An Historical Study of Iowa, I870-I930," unpub. paper, Newberry Library (Chicago, Il. I976), collected a sample from the original cards stored in Des Moines and linked it to both the I925 Iowa State Census and the federal population manuscripts. Daniel Scott Smith, "The Number and Quality of Children': Education and Marital Fertility in Early Twentieth-Century Iowa," Journal of Social History, XXX (I996), 367-393, collected another sample designed for a fertility project. 
explore, in Table 3, county-wide variation in high school education.

THE HIGH SCHOOL MOVEMENT IN IOWA: COUNTY-LEVEL ANALYSIS The county-level data that we have at our disposal contain a rich set of variables. Many wealth and income variables are available, including per capita (or per farm) values for land and crops, and the assessment of property for taxes. Detailed information exists about church going, the number of congregations, the demographic and ethnic composition of the population, and the occupational distribution of the population in Iowa's counties c. I9I5. The regressions presented in Table 3 are illustrative of a broader set of results using alternative wealth and income measures. Measures of county wealth and agricultural income have strong positive effects on high school and college attendance. None of the ethnic-composition variables matter once the proportion of the population with native parentage is included. The share of Catholics in the county population is negatively correlated with high school attendance, but the variable is highly collinear with the share of the population with foreign-born parents. The dependency ratio (fraction of those younger than five years) matters negatively for high school attainment and attendance rates, and indicators of the presence of a college in the county are positively related to high school attendance.

Of most interest regarding the issues raised in this study is that the proportion attending, or ever attending, high school reached a peak in those counties with the largest share of their population in the smallest of Iowa's towns-incorporated areas with fewer than I,700 persons. The case of those who ever attended high school shows a Io percentage point difference between the effects of county population share in the largest cities and those in the smallest towns. In the case of those currently attending, the difference is more than 4 percentage points, even in the reported regression models in Table 3 with controls for the income, wealth, and demographic composition of the population. The finding is similar to that derived from the somewhat less reliable school-attendance data in the I9Io and I920 Public Use Micro-data Sample of the U.S. population census, and it appears to be robust even with the inclusion of wealth or income measures as controls. There appears to be compelling evidence that the early 


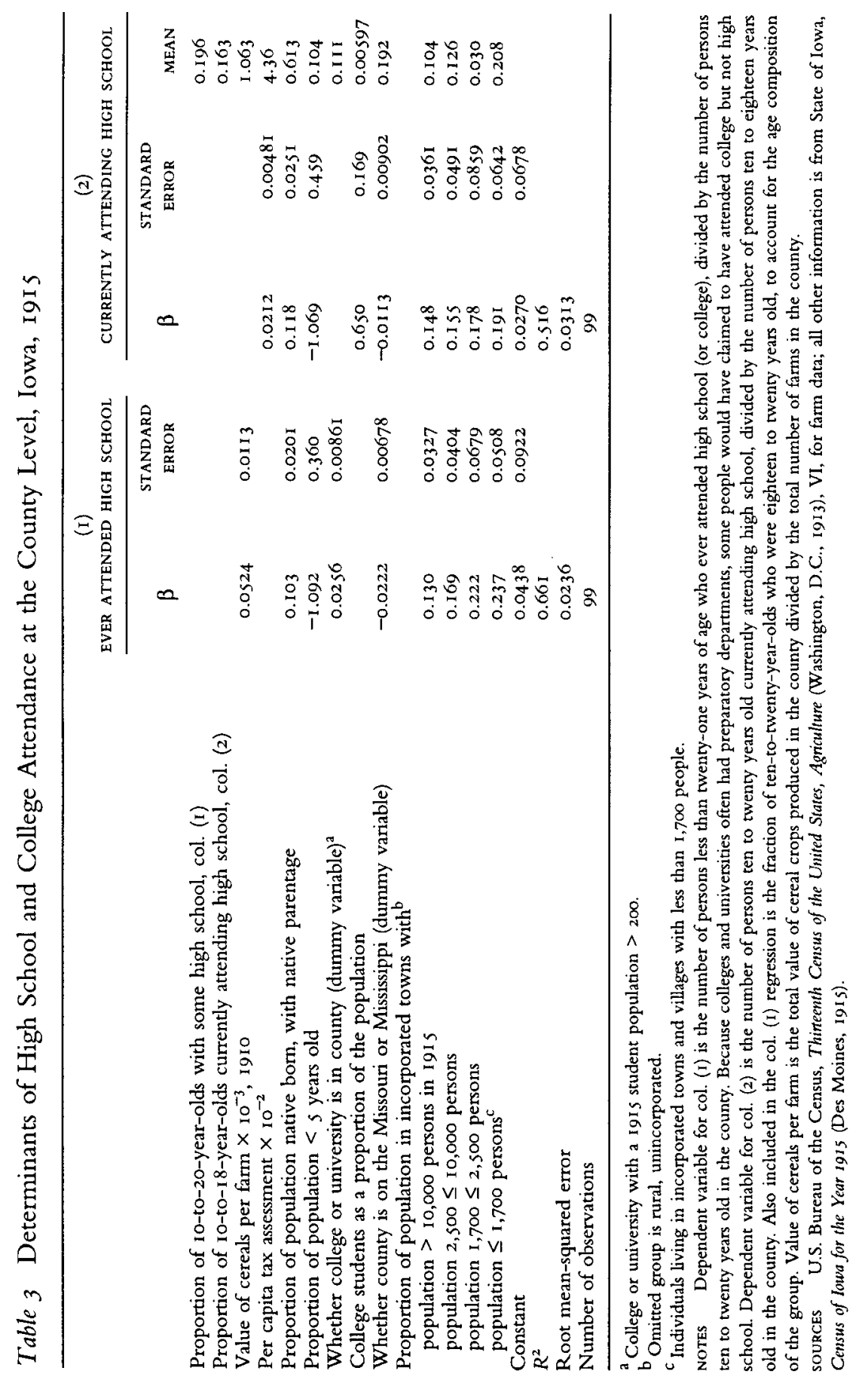


high school movement was most strongly felt in the small towns and villages of the West and Midwest. ${ }^{23}$

Why these small places had the highest rates of high school attendance is not entirely clear at this point. One possibility is that small-town America offered young people virtually nothing else to do during much of the year. In the open country, they could work on the farms, and they had limited access to secondary schools in any event. In the larger cities, they could find employment in a number of jobs. But those in the smaller towns may have had neither option.

Another potentially complementary reason is that small-town America was a locus of associations (religious, fraternal/sororal, business, and political organizations) that could have played an important role in galvanizing support for the provision of local publicly provided goods, including high schools. By all accounts, the towns and villages across America were teeming with such associations. Although they may not have provided the direct impetus for the high school movement, they certainly provide another indicator of community cohesion. ${ }^{24}$

We have attempted to assess the extent to which the differences in educational attainment by size of place reflect the density of such associations by adding a variable that measures the number of church congregations per capita to the regression specifications shown in Table 3. Church congregations per capita for Iowa counties c. I9I5 were positively related to the share of the population in small towns and negatively related to the share in larger cities. The variable has a positive but insignificant relationship to the fraction of youth who ever attended high school, and its inclusion only slightly reduces the substantial gap in high school

23 These findings are also corroborated in an analysis, not presented here, using the individual-level data from our "rural" sample. We have matched the post-office addresses or town given in the Iowa census to information about the size of the town. Among fifteento-twenty-year-olds, those residing in towns of between I,O0O and 3,500 population attained the greatest number of years of high school and college. We also include controls for county, Iowa City, sex, church affiliation, nativity of parents, whether the household head was a farmer, and an indicator variable for whether the individual could be matched to a household head.

24 Gerald Gamm and Robert D. Putnam, "The Growth of Voluntary Associations in America, I840-1940," published in this issue, find that the smallest towns in their sample had the largest number of associations per capita and that the largest cities had the smallest number. The towns in their study, however, are somewhat larger than those we are able to identify in the Iowa data. 
attainment between the smallest towns and the largest cities found in column (I) of Table 3. In contrast, church congregations per capita has a strong positive and statistically significant relation to the fraction of youth currently attending high school. It attenuates the weaker differences by size of place when it is added to the specification in column (2) of Table 3. The greater high school attendance rates in small towns seems to be partially mediated by a thicker density of community and religious associations.

Even if associations were not the glue that bound the residents of small-town America closer together, other aspects of the small town might have been. Small towns simply had greater ethnic, religious, cultural, and economic homogeneity. Whatever the underlying reasons, we have uncovered convincing evidence that the smaller towns of Iowa had the highest rates of secondaryschool attendance.

WHO GAINED FROM THE HIGH SCHOOL MOVEMENT IN IOWA, C.I9I 5 ? Thus far, we have explored differences in high school (and college) attendance by county, showing the importance of county-specific factors that could reflect differences in social capital. The smallest towns and villages, literally at the edge of the prairie, had higher levels of school attendance than did the larger towns and cities. We now move to an analysis of the impact of individual factors, those generally reflecting family background. Social and group factors, however, remain integral to the analysis.

The data are a sample of the individual records from the Iowa State Census of I9I 5 , the published version of which formed the basis of the county analysis, for three major cities (Davenport, Des Moines, and Dubuque) and eight counties, each without a city containing more than 25,000 people. The two parts of the sample are termed "three large cities" and "counties without large cities." These counties were not simply farming areas; they contained many of the towns and villages that featured in the previous discussion. The samples together contain more than 53,000 observations, almost equally divided between the cities and "rural" counties. Although the records were not arranged in family units, we have, with much success, used last names, birthplaces, addresses, and "card numbers" to reconstitute families. We describe the sample and our family reconstitution procedure in the Appendix. 
The variable of interest is the school attendance of fifteen to eighteen-year-olds, who would have been most affected by the high school movement. We consider two variants: whether the youth attended any school in I9I4 and whether the youth attended high school or college in I9I4. Although in the larger cities and towns, schooling between the ages of fifteen and eighteen would generally have taken place in a secondary school, those at the younger end of the age range could still have been in grammar school, and assessors might not have differentiated between high school and regular school. In the more rural areas, however, youths often remained in common schools into their mid-teens, especially if their districts did not contain a secondary school. But by I9I4, youths in rural Iowa no longer had to attend common schools to receive education beyond the usual eight years.

By an act of the thirty-fourth Iowa General Assembly, passed in I9I 3 after numerous attempts, all youths in Iowa had the right to attend a high school free of charge, even if their district did not have one, the tuition to be paid by their home district. This "free tuition" law, as it was termed, was one of many that states with large populations in the "open country" passed in the I9Ios and I920s. The response to the "free tuition" law in Iowa was an increase in high schools throughout the state; if taxpayers had to pay tuition, they might as well build their own schools. By I9I4, according to the Iowa State Census of I9I5, secondary-school attendance equalled 3 I percent of all fourteen-to-seventeen-yearolds..$^{25}$

25 The "free tuition" laws are not well known, and we have been unable to find a source documenting when each was passed. State education reports reveal that Nebraska's, first passed in I 895 but declared unconstitutional, was the earliest. A bill that met the constitutional objection was enacted in 1907 after two more unsuccessful tries. Some states (for example, California, Kansas, Oregon, and Washington) passed free tuition laws at the county level. By the mid-I920s, virtually every state with a large rural population had a free tuition law on its books. See William R. Hood, Legal Provisions for Rural High Schools (Washington, D.C., I925).

The high school enrollment rate computed from the Iowa State Census of I9I5, using the ratio of the number of individuals of all ages who indicated that they attended high school in I9I4 to the total number of fourteen-to-seventeen-year-olds, is almost identical to an analogous one computed from a set of contemporaneous records from high schools. The former estimate is 3 I.I percent, whereas the latter estimate is $3 \mathrm{I} .5$ percent. We compute the former estimate by weighting the figures derived from the two parts of our sample (large cities and counties without large cities) - the weights being chosen to produce estimates representative of the overall state population in large cities and in counties without large cities 
Why did some youths attend high school and others not? Table 4 reveals the effects of family background and individual characteristics on school attendance within counties and cities. In the fifteen-to-eighteen-year-old group, and among those whom we could match to household heads, 3 I percent attended high school (or college) in the large cities and 24 percent in the eight rural counties. Almost 57 percent attended any school in the large cities and 55 percent in the rural counties. ${ }^{26}$

Among the determinants of attendance in high school (or college)-columns (3) and (6) of Table 4-are such characteristics as sex, church affiliation, and own and parental birthplace. Features of the household head, such as occupation, years of schooling, and home or farm ownership, are also included. Not surprisingly, youths from privileged families had a far higher probability of attending high school than others. The son or daughter of a household head who was a white-collar worker and had graduated from secondary school was 30 percentage points more likely to attend high school in the large cities than was the child of a blue-collar worker with eight years of school. A similarly large gap in the rural counties is apparent between youths living with a head of household who was a white-collar worker and those living with one who was a farmer. Foreign birth, for the child or the parents, was far less important, once education and occupation of the household head are included. Girls were more likely to attend school in the counties without large cities but not in the three large cities. Many have reported sex differences in secondary-school education, particularly in industrial settings, but the Iowa data reveal smaller differences. ${ }^{27}$

in I9I5. The procedure for latter estimate, derived from a completely different set of data, is in Goldin, "Appendix."

26 The rural attendance rates are lower than those in the three large cities because the rural data include those in the "open country." The data from the Iowa State Census of I9Is enable a more accurate calculation of the percentage of youths attending school than do the federal population censuses of I9IO and I920. School attendance in the Iowa State Census is given in months. A few students attended school for fewer than six months; most attended for nine and some for eight.

All the regressions in Table 4 have also been estimated using logits and probits with no important change in the underlying conclusions. We report the easier-to-interpret linearprobability models with appropriately adjusted robust standard errors.

27 Head of the family status was inferred using a simple algorithm that bestows head status to a married male in the household who meets various age criteria with respect to the children, or to a widowed or divorced male in the household in the absence of a married woman. In 
The coefficients on church affiliation have enormous significance. The I9I5 Iowa State Census is the earliest known United States document to give information about education and religion, as well as various economic variables for a large representative sample. Affiliation with any of the New England Protestant churches, including Congregational, or with a Jewish synagogue, increased the probability of attending high school by 20 to almost 30 percentage points above that of a person with no church affiliation in the city sample. The effect in the rural counties was highest for Congregationalists but remained substantial for the other New England Protestants. Those with no church affiliation in the city sample had the lowest school attendance. Certain religious denominations, such as Congregational and Quaker, founded liberal arts colleges and universities and had a long-standing involvement in education. But the difference between the group with no church affiliation and the others might have been due to the association of church affiliation in I9I 5 , like today, with sociability in other dimensions and thus with parental pressure to keep children in school. ${ }^{28}$

Family characteristics were undoubtedly important in determining high school attendance. The more privileged may have taken greater advantage of the public school system, but the vast majority of the children in Iowa's high schools had more humble backgrounds. In the city sample, 64 percent of the fifteen to eighteen-year-olds in households headed by high school graduates were attending high school (or college) in I9I4, compared with 27 percent of those in households headed by non-high school

the rural sample, 86.3 percent of the household heads were male and 9.4 percent were widowed (or divorced) women. In both samples, only 5 percent of household heads were married women who either did not correctly state their marital status or whose husbands were not found in the census. The inclusion of head's income and country of origin dummies does not alter the main results.

On sex differences in high school enrollment and graduation, see Goldin, "America's Graduation from High School," and on co-education in general, see Tyack and Elisabeth Hansot, Learning Together: A History of Coeducation in American Schools (New Haven, I990). 28 See Edward Glaeser and Spencer Glendon, "The Demand for Religion," Harvard University working paper (Cambridge, Mass., I997) for the relationship between economic success and religion using modern data. They find that individuals claiming no religious belief have similar amounts of education than those with religious beliefs, but have far lower incomes. Note that the Iowa State Census asked "church affiliation," whereas Glaeser and Glendon use a question on religious belief. The variable in the I9I5 Iowa State Census is an associational measure rather than one concerning beliefs. 


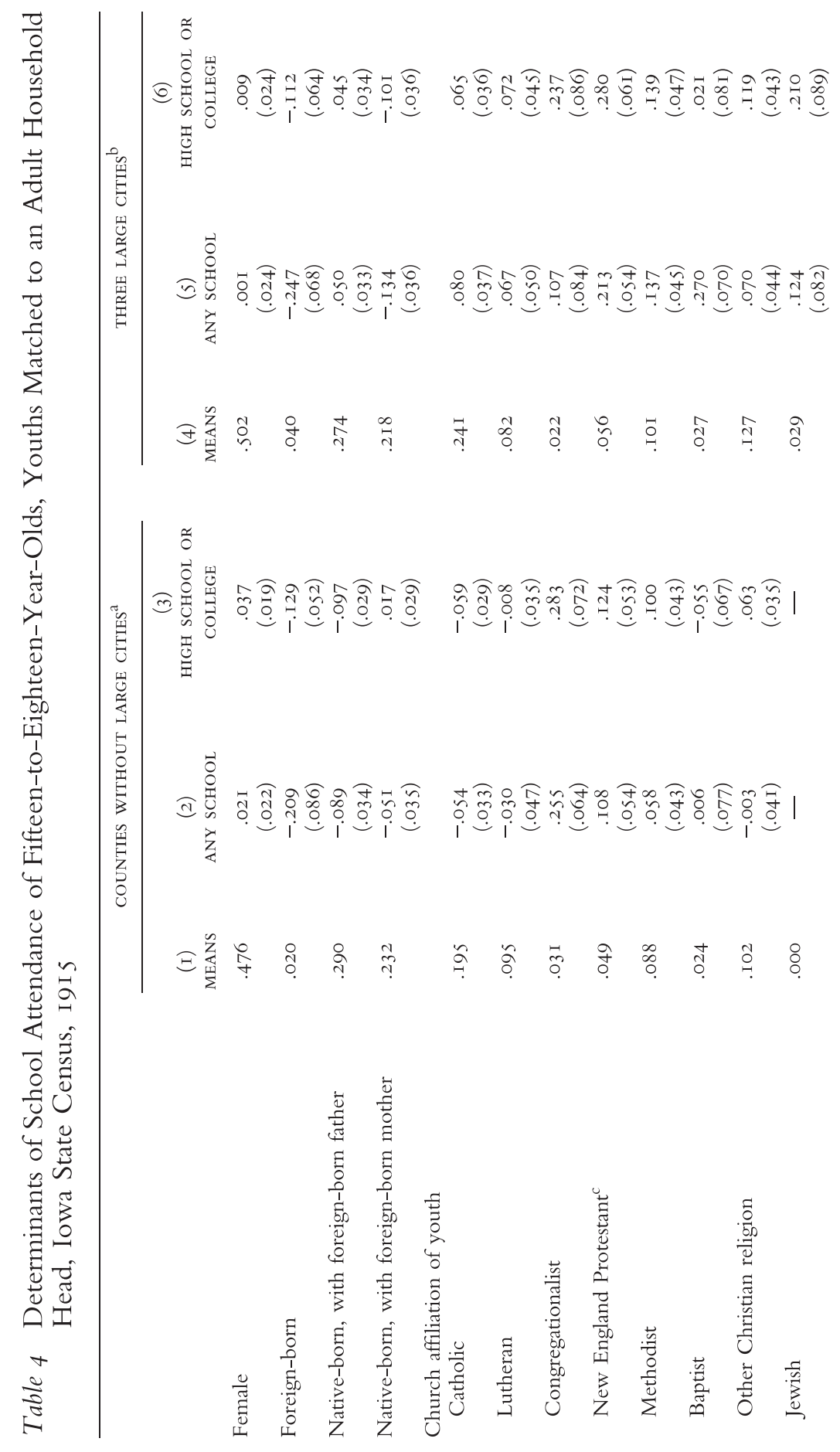




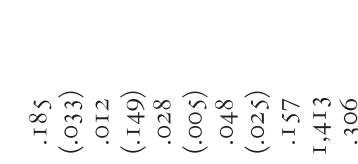

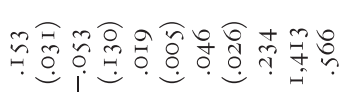

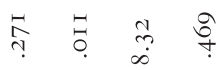

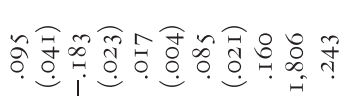

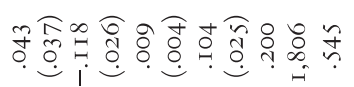

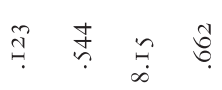

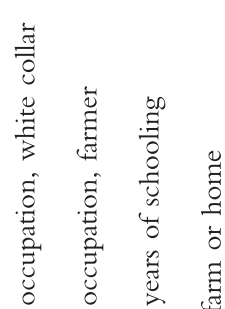

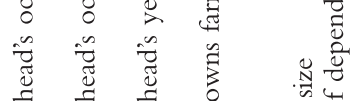

$$
\begin{aligned}
& \text { 音 音 音 }
\end{aligned}
$$

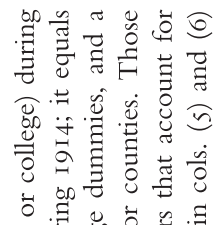

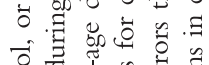

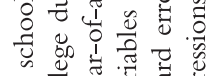

$$
\begin{aligned}
& \text { 点节范焉焉 }
\end{aligned}
$$

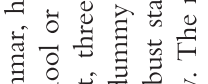

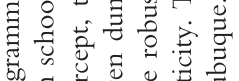

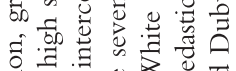

$$
\begin{aligned}
& \text { 手和 } \\
& \text { 记 }
\end{aligned}
$$

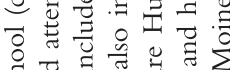

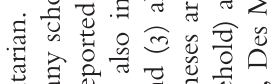

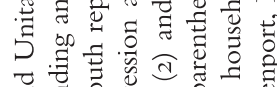

$$
\begin{aligned}
& \text { चี }
\end{aligned}
$$

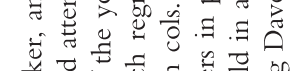

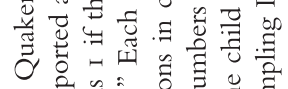

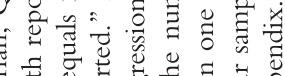

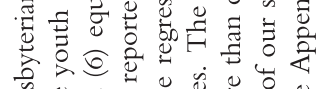

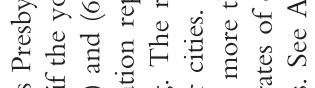

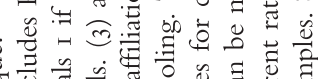

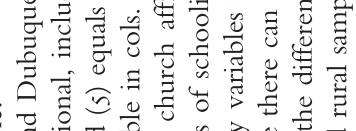

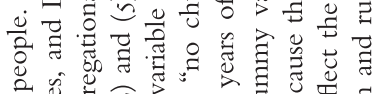

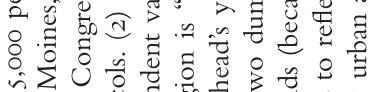

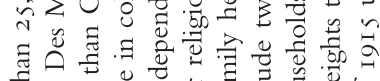

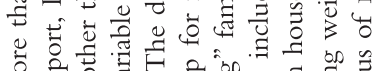

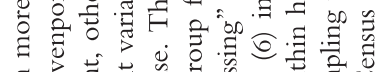

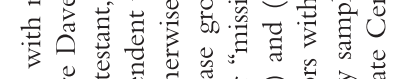

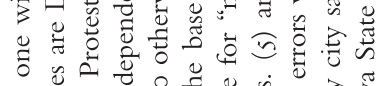

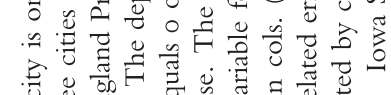

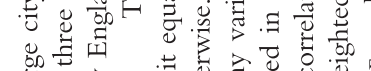

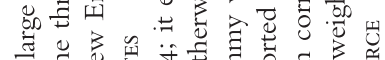


graduates. Yet, even though those from more privileged backgrounds disproportionately attended high school, just 20 percent of high school students came from families in which the household head was a high school graduate. Similar results obtain in the rural counties (even excluding the farm population). That differences existed by parental background is understandable. The important point is that despite these differences, the vast majority of public high school students in Iowa had parents who did not have a high school diploma and were not white-collar workers. The non-elites were sufficiently numerous to have easily voted for the greater expenditures to support the high schools. ${ }^{29}$

WHAT WERE THE RETURNS TO HIGH SCHOOL IN IOWA, C.I9I5? At the outset of this article, we noted that many of the reasons for the expansion of secondary education could be traced to the pecuniary returns to attending high school. The problem for those researching the subject has been the lack of national data on education and earnings before the federal census of I940. In a previous study comparing earnings for occupations that generally demanded secondary schooling with earnings for occupations that did not, we found a substantial wage premium at the start of the high school movement. The Iowa State Census sample enables a more direct estimation of the returns to high school for the population reporting occupational income for I9I4. Table 5 reports results from estimating log (annual earnings) equations for three groups of non-farm workers-males eighteen to seventy years old, males eighteen to thirty-four years old, and unmarried females eighteen to thirty-four years old. The specifications include measures of schooling attainment, and controls for potential labor-market experience, nativity, and years in the United States for the foreign born. ${ }^{30}$

29 Educational differences by family background would also have been large if we had considered elite occupations rather than the schooling of the household head. George S. Counts, "The Selective Character of American Secondary Education," The School Review and The Elementary School Journal, XIX (May I922), 40, made similar points about differences in school attendance by father's occupation in Mt. Vernon, N.Y. But in Count's data, by the senior year of high school, almost 88 percent of all students were the children of white-collar workers, whereas 49 percent were in sixth grade.

30 On earnings for different occupations and the educational wage premium, see Goldin and Katz, "Decline of Noncompeting Groups." 
Table 5 Estimates of the Returns to Education by Type of Schooling for Non-Farm Occupations from Log(Annual Earnings) Regressions, Iowa State Census, I9I5

\begin{tabular}{|c|c|c|c|}
\hline & $\begin{array}{l}\text { MALES, } \\
\text { I } 8 \text { TO } 70 \\
\text { YEARS }\end{array}$ & $\begin{array}{c}\text { MALES, } \\
\text { I } 8 \text { TO } \\
34 \text { YEARS }\end{array}$ & $\begin{array}{l}\text { FEMALES, } \\
\text { UNMARRIED, } \\
\text { I } 8 \text { TO } 34 \\
\text { YEARS }\end{array}$ \\
\hline \multicolumn{4}{|l|}{$\begin{array}{l}\text { Linear spline function in } \\
\text { education }\end{array}$} \\
\hline Years of common school $\leq 9$ & $\begin{array}{l}.046 \\
(.004)\end{array}$ & $\begin{array}{c}.070 \\
(.006)\end{array}$ & $\begin{array}{l}.016 \\
(.012)\end{array}$ \\
\hline Years of common school $\geq$ IO & $\begin{array}{l}.007 \\
(.01 \mathrm{I})\end{array}$ & $\begin{array}{l}.009 \\
(.018)\end{array}$ & $\begin{array}{l}.022 \\
(.027)\end{array}$ \\
\hline Years of grammar school $\leq 9$ & $\begin{array}{l}.07 \mathrm{I} \\
(.004)\end{array}$ & $\begin{array}{l}. \text { IOI } \\
(.006)\end{array}$ & $\begin{array}{l}.060 \\
(.0 \mathrm{II})\end{array}$ \\
\hline Years of grammar school $\geq$ Io & $\begin{array}{l}.032 \\
(.019)\end{array}$ & $\begin{array}{l}.027 \\
(.024)\end{array}$ & $\begin{array}{l}-.002 \\
(.062)\end{array}$ \\
\hline Years of high school & $\begin{array}{l}.104 \\
(.005)\end{array}$ & $\begin{array}{l}.119 \\
(.006)\end{array}$ & $\begin{array}{l}.125 \\
(.008)\end{array}$ \\
\hline $\begin{array}{l}\text { Years of college } \times \text { (years of high } \\
\text { school }>0 \text { ) }\end{array}$ & $\begin{array}{l}.098 \\
(.006)\end{array}$ & $\begin{array}{l}.122 \\
(.009)\end{array}$ & $\begin{array}{l}. \mathrm{I} 45 \\
(.014)\end{array}$ \\
\hline $\begin{array}{l}\text { Years of college } \times \text { (years of high } \\
\text { school }=0 \text { ) }\end{array}$ & $\begin{array}{l}.047 \\
(.017)\end{array}$ & $\begin{array}{l}.102 \\
(.035)\end{array}$ & $\begin{array}{l}.026 \\
(.047)\end{array}$ \\
\hline $\begin{array}{l}\text { College but no high school, } \\
\text { dummy }\end{array}$ & $\begin{array}{l}.28 \mathrm{I} \\
(.053)\end{array}$ & $\begin{array}{l}.172 \\
(.085)\end{array}$ & $\begin{array}{l}.4 \mathrm{I} 4 \\
(. \mathrm{II} 3)\end{array}$ \\
\hline Business school, dummy & $\begin{array}{l}.403 \\
(.074)\end{array}$ & $\begin{array}{l}.28 \mathrm{I} \\
(.088)\end{array}$ & $\begin{array}{l}.474 \\
(.100)\end{array}$ \\
\hline Native-born & $\begin{array}{l}.206 \\
(.027)\end{array}$ & $\begin{array}{l}.129 \\
(.035)\end{array}$ & $\begin{array}{l}-.0 \mathrm{II} \\
(.08 \mathrm{I})\end{array}$ \\
\hline \multirow[t]{2}{*}{$\begin{array}{l}\left(\text { Years in U.S. } \times \mathrm{IO}^{-2}\right) \times \\
\text { foreign-born }\end{array}$} & .488 & $.26 \mathrm{I}$ & -.004 \\
\hline & $(.095)$ & $(.258)$ & $(.006)$ \\
\hline$R^{2}$ & .233 & .270 & .310 \\
\hline $\begin{array}{l}\text { Standard error (root } \\
\text { mean-squared error) }\end{array}$ & .580 & .526 & .554 \\
\hline Number of observations & I0,734 & $5, \mathrm{I} 69$ & I, 897 \\
\hline
\end{tabular}

NOTES The dependent variable in each regression is $\log$ (total annual earnings for I9I4 from occupation). Each regression also includes an intercept, a quartic in potential experience (age - total years of schooling - 6), a non-white dummy, and a dummy for whether years in the United States is missing. The samples consist of all individuals in the appropriate age-sex-marital-status group in non-farm occupations reporting positive I9I4 earnings, without missing data for age, schooling, race, or nativity. The regression pools the sample containing counties without large cities and that with the three large cities (Davenport, Des Moines, and Dubuque). Observations are weighted to reflect the different sampling rates in the two samples to make the regressions representative for the entire population of Iowa (except for individuals in the rural areas of counties containing large cities).

SOURCE Iowa State Census of igis urban and rural samples. See Appendix. 
The schooling-attainment measures given in the Iowa State Census allow us to differentiate among various types of schools. Most Iowans living in the open country would have attended a common school for their elementary years, whereas their urban counterparts would have gone to a grammar (or graded) school. Members of either group could have continued to high school, college, business school, or any other type of school. Early in this century, many individuals went to common and grammar schools for more than eight years. In some cases, as discussed earlier, common schools took up the task of educating rural teenagers who did not have high schools to attend. In other cases, however, common-school attendance beyond eight years meant that the student had been "retained," or held back. We can compute the returns to years of common- and grammar-school education beyond the usual number to see whether the added years substituted for secondary school or were simply remedial by entering the schooling variables as a linear spline function. ${ }^{31}$

Most important to our understanding of the high school movement is that the return to a year of secondary school is substantial in all three estimations. It is Io percent for males of all ages, I 2 percent for the younger group, and I 2.5 percent for the younger group of females. The returns per year of high school are about equal to those for each year of college. ${ }^{32}$

Since it was not unusual in the nineteenth and early twentieth centuries for individuals to have attended college without having gone to high school-either because they went to a preparatory department of a college or because they were tutored at homewe must include variables accounting for returns to years of college when years of high school were zero. Three college variables are entered: One interacts years of college with a dummy variable when years of high school are greater than zero; one interacts years of college with a dummy variable when there is no

3 I See Goldin, "America's Graduation from High School," on the importance of figuring out whether the added years should be considered as secondary or grammar school. Older Americans in 1940- the first year when the federal census inquired about educational attainment - appear to have vastly overstated their years of education in comparison with data from secondary schools, contemporaneous with their possible attendance. One possibility is that many Americans attended grades nine through twelve in common schools.

32 The estimated returns to high school are similar in specifications that also include controls for church affiliation, county, city, and parents' nativity. 
high school; and one is a dummy variable for college when there is no high school. The results suggest that the returns to a year of college in the absence of high school, for the younger group, are about the same as those to a year of high school. That is, young men who did not list any high school but who went on to college most likely attended the preparatory department of their college or university. The business school dummy is substantial for both men and women. ${ }^{33}$

The returns to the lower grades show that extra years of either common- or grammar-school education had scant returns, if any. That is, extra years at the elementary school level do not appear to have substituted in any way for years in high school. The return to a year of high school was considerably higher than for the extra years at the lower grades. Only for the older men in the sample did the return to more than ten years of grammar school amount to a nontrivial magnitude, but even then, it was one-third of that earned for a year of high school.

In sum, the returns to education by type of schooling for non-farm occupations show that secondary education had a substantial payoff in Iowa c. I9I 5 . A return on the order of 12 percent per year is one-and-one-half times the return to a year of college in I980, and about the same as that to a year of college in 1995 , a time when returns are considered to have been notably high. ${ }^{34}$

The high school movement, which picked up steam around I9Io in the Great Plains, Far West, and parts of New England and the Midwest, was an enormous undertaking for local government. The cost of moving a generation of young people through four years of high school was equal to, if not more than, the value of

33 The returns that we calculate do not net out the direct costs of education, which would have been substantial for many business schools but close to zero for public high schools. Most individuals who stated that they attended a business school went for few years, if that. Thus the returns to business school, even netting out the costs, are enormously high. Many of the younger males with business-school training were bookkeepers, and many of the females were stenographers. The high returns in I9I5 indicate why high schools began to offer commercial courses and why young people flocked to commercial schools in the I9IOs and I920s.

34 David H. Autor, Lawrence F. Katz, and Alan B. Krueger, "Computing Inequality: Have Computers Changed the Labor Market?” NBER working paper 5956 (Cambridge, Mass., I997), Table I, report that a year of college in I 995 had a I2 percent return but only an 8 percent return in 1980 . 
the resources used to educate them to the eighth grade. Yet, community after community swiftly built high schools and hired qualified teachers.

The reasons why parents wanted their children educated and why their teenagers readily flocked to the schools are clear. First and foremost, secondary schooling brought extremely high returns for both males and females c. I9I5. Some of the returns were garnered by those who left their rural homes and moved to towns and cities. But even in Iowa the returns were substantial. Young people did not have to leave even this largely rural and small-town state to profit from the human capital acquired in high school c. I9I5. Our estimates, derived from a unique set of manuscriptsthe Iowa State Census of I9I 5-reveal that the return to a year of high school was about $\mathrm{I} 2$ percent. But why did the public take up this expensive provision of a relatively private good?

Analysis of a cross section of states in I9IO and 1928 reveals that homogeneity of residents - in the form of ethnicity, religion, and income - a high level of wealth or income, and a community made stable by a strong presence of older people increase the apparent support for high schools in the early to middle years of the movement. Smaller towns and villages in the United States were the locus of the movement's activity; high school attendance there was the greatest. We suspect that these small towns and villages were reservoirs of social capital that helped to fuel the high school movement. The only consistent rationale for the public provision of this essentially private good was that it was an intergenerational loan from one generation to the next. Although we cannot fully disassociate the roles of alternative activities for teenagers from the existence of social capital, our evidence is more consistent with the latter than the former. The areas of the country with the greatest tangible wealth and seemingly the greatest intangible wealth, or social capital, witnessed the earliest and the most rapid diffusion of the high school movement.

Many of the leading states of the high school movement continue to score high on various social-capital indicators today. The state-level correlation of the I928 high school graduation rate with a current social-capital index combining five factors (measuring associational activity, social trust, and political/civic participation) is 0.64 (see Figure 4, upper panel). In the absence of two outliers (North Dakota and Nevada, two of the least populous 
states), the correlation is $0.8 \mathrm{I}$. Current measures of social capital are more highly correlated with various economic indicators of the early twentieth century than with more recent ones. For example, the correlation with the log of per capita wealth in I9I 2 is 0.73 (excluding Nevada); the correlation with the log of agricultural income per farm worker in 1900 is $0.7 \mathrm{I}$ (0.86 without California and Nevada); and the correlation with per capita income in I900 is 0.6I (0.72 without California and Nevada). In contrast, the correlation with a current income measure-the log of per capita income in I994-is $0.22 .{ }^{35}$

States that led in the high school movement continue to lead in educational quality indicators, as shown in the lower panel of Figure 4. The correlation between a current index of educational performance and the high school graduation rate in 1928 is 0.60 (0.73 without California and Nevada). The social capital assembled in the early part of this century, which apparently helped to drive the high school movement, appears to survive today in some form and to contribute to human capital formation even today. ${ }^{36}$

\section{APPENDIX: THE I9I5 IOWA STATE CENSUS PROJECT}

The I9I5 State Census of Iowa was the first state or federal census to include information about education and income prior to the federal census of I940, and it contains considerable detail about other aspects of individuals and households - for example, church affiliation, which was never solicited in a federal census; wealth; and years in the United States and in Iowa. It is a complete sample of the residents of the state.

35 We thank Putnam for providing us with his indices of social capital and educational performance. See Jay Braatz and Putnam, "Families, Communities, and Education in America: Exploring the Evidence," Harvard University working paper (Cambridge, Mass., I997). The social-capital index is defined in the notes to Figure 4. The reported correlation coefficients in this paragraph and that following cover the "lower forty-eight" states except where indicated. State per capita income data in I900, and state agricultural income per farm worker data in I900, are from Simon Kuznets, Ann Ratner Miller, and Richard A. Easterlin, Population Redistribution and Economic Growth: United States, 1870-1950. II. Analyses of Economic Change (Philadelphia, I960). State per capita wealth data for I9I2 are from U.S. Department of Commerce, Statistical Abstract of the United States (Washington, D.C., I925). State per capita income data in 1994 are from U.S. Department of Commerce, Statistical Abstract of the United States (Washington, D.C., I996).

36 The state educational-performance index combines three factors. See Braatz and Putnam, "Families, Communities, and Education in America." The educational-performance index is defined in the notes to Figure 4. 
Fig. 4 Recent Social-Capital and Educational-Performance Indices, and the I928 High School Graduation Rate
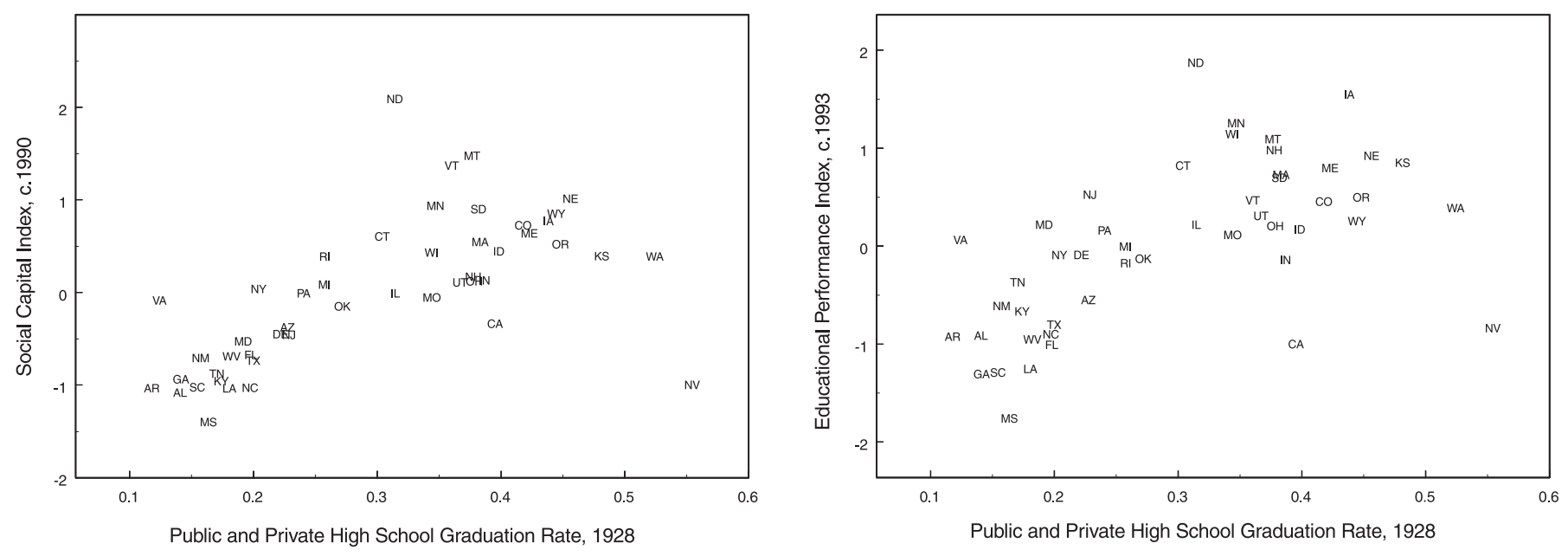
SOURCES For the social-capital index, see Jay Braatz and Robert D. Putnam, "Families, Communities, and Education in America: Exploring the Evidence," Harvard University working paper (Cambridge, Mass., I997). The index is an unweighted mean of the Z-scores of five components: (I) 5OI (c) (3), that is, non-profit, organizations per capita in I989; (2) daily newspaper circulation per capita in I99I, capped for three states (Massachusetts, New York, and Virginia) to avoid bias from nationally circulated newspapers; (3) mean voter turnout in the presidential elections of I988 and I992; (4) the average number of associational memberships per capita from the General Social Survey-Inter-university Consortium for Political and Social Research (ICPSR) electronic data-all available years from I974 to I994; and (5) the social-trust measure from the General Social Survey, all available years from 1972 to I996. For the educational-performance index, see Braatz and Putnam, "Families, Communities, and Education." The index average three components: (I) a combination of seven National Assessment of Educational Progress scores for 1990, I992, and I996; (2) the average Scholastic Aptitude Test score in I993, adjusted for participation-rate differences among states; and (3) a measure of the high school dropout rate for I990 to I995 that combines four factors. For the I928 high school graduation rate, see Goldin, Appendix to "How America Graduated from High School: An Exploratory Study, I9Io to 1960," National Bureau of Economic Research-Development of the American Economy working paper 57 (Cambridge, Mass., I994). The rate is computed as the ratio of public and private graduates to the number of seventeen-year-olds in the state. 
The returns-written by census takers (assessors) on index cards, one for each individual - were deposited in the Iowa state archives in Des Moines and microfilmed by the Genealogical Society of the Church of Jesus Christ of Latter-day Saints (Mormons) in I986.

The census cards, now on microfilm, are grouped by county, although the large cities (those having more than 25,000 residents) are grouped separately. Within each county or large city, all records are alphabetized by last name and within last name by first name (notwithstanding occasional errors). The current project has sampled the records for three of the largest Iowa cities-Davenport, Des Moines, and Dubuque. We planned to sample Sioux City, but the microfilms are too light. Counties that did not contain a city of more than 25,000 people in I9Io have also been sampled. The counties were chosen by grouping the ninety-nine counties in Iowa in four equal-sized units by education and then randomly taking three from each of the four groups. This procedure produced twelve counties, eight of which (Adair, Buchanan, Carroll, Clay, Johnson, Lyon, Marshall, and Wayne) have been sampled thus far. They conveniently span much of the geography of the state: Clay and Lyon in the northwest, Johnson and Buchanan in the east, Wayne in the south central, Marshall in the central, Carroll in the west central, and Adair in the southwest.

\section{SAMPLING STRATEGY FOR THE URBAN AND RURAL SAMPLES}

Urban Sample. For each of the cities, about one-fourth of the films, distributed throughout the alphabet, were purchased. We took every other name on each roll of microfilm chosen for the sample and entered only completed last names; for example, the first name on a roll was not taken. If the cards did not go in alphabetical order, we attempted to reorder them.

Rural Sample. For each of the counties, one film (from a total of four to seven, depending on the county) was purchased. We sampled all names on each roll of microfilm chosen for Buchanan, Carroll, Lyon and Marshall, and one-half of the names for Adair, Clay, Johnson, and Wayne.

VARIABLES INCLUDED All variables on the census cards were taken for the data collection (in order of recording): card number, sex, color, marital status, months of schooling in I9I4 by type of school (public elementary, private elementary, high school, or college), ability to read and/or write, handicaps (blind, insane, deaf, idiot), naturalization status (if foreign-born), years in Iowa and years in the United States, full name, age, address (county, post office, town or township, and ward), occupation, months unemployed and total earnings from occupation for I9I4, extent of education (years in common, grammar, high school, college), birthplace, home or farm ownership, incumbrance on and value of the same, military service, church affiliation, father's and mother's birthplaces, assessor's name, and any remarks on the card. 
FAMILY RECONSTITUTION Entire households were surveyed, but because the cards were boxed alphabetically, we can reconstitute only nuclear families in which all members have the same last name. Our interest was in grouping parents with their dependent children. The assessors numbered each of the cards, almost always in sequential order within a household. Additional information was provided by address (particularly important for the cities, although P.O. address was not given in Davenport), parents' places of birth, and the assessor's name. We used all these pieces of information to reconstitute the families, although we primarily used card number, last name, and address. Of those aged fifteen to eighteen in the rural-county sample, we matched 89. I percent to an adult household head; we matched 78.7 percent in the large-city sample.

For several reasons, we could not match all teenaged children to parents or guardians. First, children and their guardians did not always have the same last name. Some children had been orphaned; some boarded with relatives to advance their education; and others boarded for reasons of work. Second, cards of parents were sometimes alphabetized incorrectly or the last names misspelled. Since two of the cities provided complete addresses, misspelling would have been less of a problem. But because we skipped every other name, we could have missed parents whose last names were alphabetized differently from that of their children. There are many reasons, some pertaining to early twentieth-century life and others having to do with late twentiethcentury data collecting, why all families could not be reconstituted.

DUPLICATE CARDS Because the census was taken over a period of time (we do not know how long), we term individuals who appear more than once in the sample the "duplicates." In some cases, the origin of the "duplicate" is clear: The individual was in an asylum or a school and was counted in both places. In other cases, the individual apparently moved or went through some other life transition, such as marriage. Certain ethnic groups (Russian Jews, for example) and blacks were more apt to be counted twice, probably because of their greater frequency of moving. We coded one record as the original and one as the duplicate; we do not use the duplicated information in our sample. About 2 percent of the urban sample were duplicates; practically none of the rural sample was. 